\title{
Protein Denaturation Through the Use of Magnetic Molecularly Imprinted Polymer Nanoparticles
}

\author{
Charlotte Boitard, Aude Michel, Christine Ménager * (D) and Nébéwia Griffete *
}

PHysico-Chimie des Electrolytes et Nanosystèmes InterfaciauX (PHENIX), Sorbonne Université, CNRS, 4 Place Jussieu, 75005 Paris, France; charlotte.boitard@orange.fr (C.B.); aude.michel@upmc.fr (A.M.)

* Correspondence: christine.menager@sorbonne-universite.fr (C.M.); nebewia.griffete@sorbonne-universite.fr (N.G.)

Citation: Boitard, C.; Michel, A.; Ménager, C.; Griffete, N. Protein Denaturation Through the Use of Magnetic Molecularly Imprinted Polymer Nanoparticles. Molecules 2021, 26, 3980. https://doi.org/ $10.3390 /$ molecules 26133980

Academic Editor:

Domenico Lombardo

Received: 1 June 2021

Accepted: 25 June 2021

Published: 29 June 2021

Publisher's Note: MDPI stays neutral with regard to jurisdictional claims in published maps and institutional affiliations.

Copyright: (c) 2021 by the authors. Licensee MDPI, Basel, Switzerland. This article is an open access article distributed under the terms and conditions of the Creative Commons Attribution (CC BY) license (https:// creativecommons.org/licenses/by/ $4.0 /)$.
Abstract: The inhibition of the protein function for therapeutic applications remains challenging despite progress these past years. While the targeting application of molecularly imprinted polymer are in their infancy, no use was ever made of their magnetic hyperthermia properties to damage proteins when they are coupled to magnetic nanoparticles. Therefore, we have developed a facile and effective method to synthesize magnetic molecularly imprinted polymer nanoparticles using the green fluorescent protein (GFP) as the template, a bulk imprinting of proteins combined with a grafting approach onto maghemite nanoparticles. The hybrid material exhibits very high adsorption capacities and very strong affinity constants towards GFP. We show that the heat generated locally upon alternative magnetic field is responsible of the decrease of fluorescence intensity.

Keywords: magnetic nanoparticles; molecularly imprinted polymer; magnetic hyperthermia; proteins; denaturation

\section{Introduction}

Cell targeting as well as the inhibition of the protein function are still challenging nowadays. Conventional methods employed to target cells, such as aptamers [1,2], nanobodies [3] or chromobodies [4] have proved to be very effective and selective, but these biological molecules are difficult to produce, requiring either animal hosts $[5,6]$ or timeconsuming synthetic pathways [7]. For example, a strategy that is used in oncology consists on the targeting of growth factors (vascular endothelial growth factor or basic fibroblast growth factor), that are secreted by cancer cells, using small organic molecules [8,9], but identification of the possible inhibitors and determination of the best one are also really expensive and time-consuming [10]. Systems that are able to both target cancer specific proteins at the tumor place, if we accumulate them, inhibit the protein by modifying their three-dimensional configuration, easy to determine and fast to produce, could be formidable tools to overcome these limitations.

Molecularly imprinted polymers (MIP), able to specifically bind molecules of interest only by knowing their structure, seem to perfectly fit these requirements. Indeed, they act as synthetic antibodies [11,12], because of the specific interactions between functional monomers and template protein, which will lead to the formation of the so-called imprints. They are tailor-made recognition sites, perfectly complementary to the target protein in terms of shape, size and functionality. Over the past few years, synthetic pathways were developed to obtain protein imprints [13] despite restrictions due to the fragile nature of these biomacromolecules, easily undergoing denaturation when submitted to the harsh conditions often used to imprint smaller molecules $[14,15]$. While MIP were initially mostly used for analytical or diagnosis purposes [16], interest focus nowadays on their use in nanomedicine, either to act as the targeting part of some drug delivery systems [17] or to inhibit the action of some proteins by making them inaccessible $[18,19]$ or even for the reversible presentation of bioactivity and dynamic control of cell-material interactions [20]. 
Coupled more and more often to magnetic nanoparticles, e.g., maghemite $\gamma-\mathrm{Fe}_{2} \mathrm{O}_{3}$, the only use made of the new magnetic properties of MIP was to facilitate their manipulation, either during preparation steps [21-23] or for magnetic targeting [24]. Moreover, the application of an alternative magnetic field (AMF) of appropriate amplitude and frequency lead magnetic nanoparticles to release heat [25]. As magnetic heating is non-invasive, present no depth penetration limit and remote controllability, its use in nanomedicine is possible. Hence, an interesting field of research concerns now is the use of specific temperature profiles at the vicinity of magnetic nanoparticles for heating with minor to no macroscopic effect (hot spot effect) [26-28]. This local heating could be interesting in oncology after the accumulation of the magnetic MIP at the tumor place, using a magnet, and the adsorption of the interesting growth factors, then the application of AMF could led to the denaturation of the protein and to its inactive form. Hence the cancer cells will stop their growth. Even if the protein could be released from the magnetic MIP, as it is in its inactive form it cannot be recognized by the cancer cells. To the best of our knowledge, this local thermal effect was never employed to denature proteins adsorbed on imprinted polymers coupled to magnetic nanoparticles.

We here present for the first time a novel concept for the inhibition of the protein function consisting on the use of magnetic molecularly imprinted polymer for the protein sequestration and the change of its chains structure using the heat dissipated by magnetic nanoparticles under AMF. We synthesized new magnetic protein imprinted polymers (labeled $\gamma-\mathrm{Fe}_{2} \mathrm{O}_{3} @ \mathrm{MIP}$ ) to target and denature green fluorescent protein (GFP). Attention was paid to the adsorption properties of $\gamma-\mathrm{Fe}_{2} \mathrm{O}_{3} @ M I P$ and the fate of adsorbed proteins. An AMF was successfully employed to take advantage of the magnetic hyperthermia properties of maghemite nanoparticles and denature the adsorbed proteins in bulk solution.

\section{Results and Discussion}

$\gamma$ - $\mathrm{Fe}_{2} \mathrm{O}_{3} @ M I P-G F P$ nano-objects were synthesized in three steps, as displayed in Figure 1a [29].
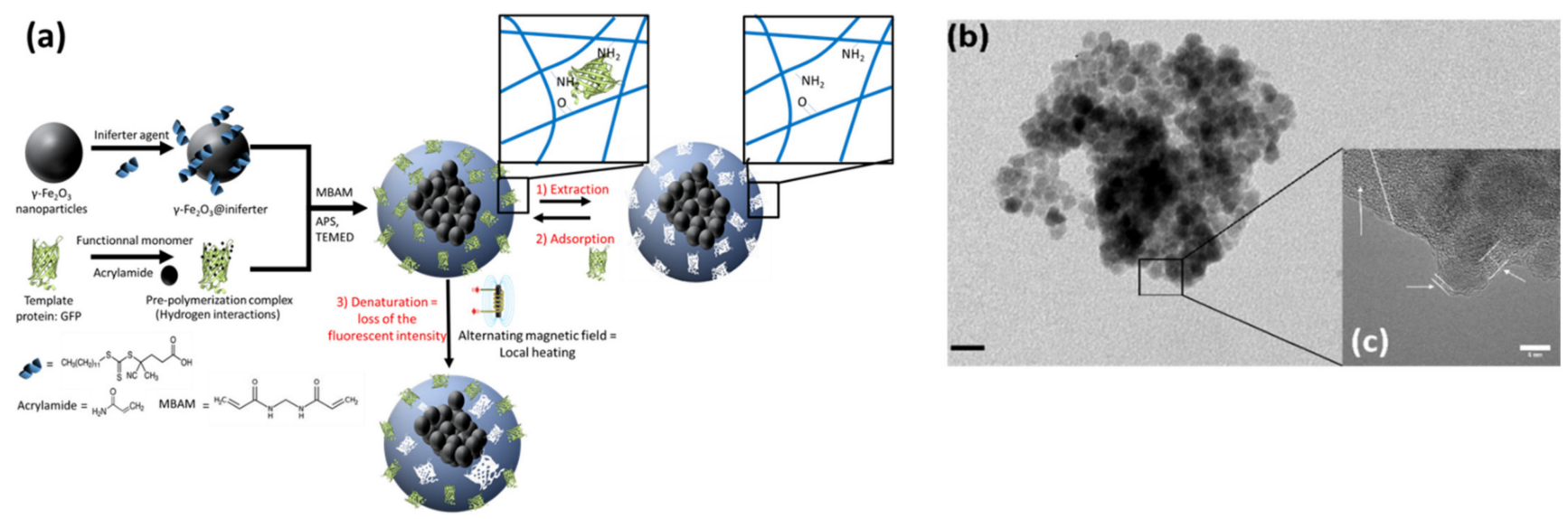

Figure 1. Preparation and characterization of magnetic GFP imprinted polymers $\gamma-\mathrm{Fe}_{2} \mathrm{O}_{3} @ \mathrm{MIP}-\mathrm{GFP}$. (a): Scheme of the synthesis approach. Template protein: here GFP; MBAM: N,N-methylenebisacrylamide; APS: ammonium persulfate; TEMED: $\mathrm{N}, \mathrm{N}, \mathrm{N}^{\prime}, \mathrm{N}^{\prime}$-tetramethylethylenediamine. $(\mathbf{b}, \mathbf{c})$ : Transmission electron microscopy of MIP-functionalized maghemite nanoparticles (b: scale bar $20 \mathrm{~nm}$, c: scale bar: $6 \mathrm{~nm}$ ). Polymer highlighted using white lines and arrows.

After synthesis of magnetic nanoparticles using a co-precipitation method, they were functionalized with an initiation-transfer-termination (iniferter) agent [30] and mixed with pre-polymerization complexes composed of GFP and acrylamide. Polymerization was allowed to proceed at room temperature in water, and magnetic non-imprinted polymers (NIP) were synthesized the same way, without the GFP. Hybrid nano-objects were imaged using transmission electronic microscopy (TEM) as displayed in Figure 1b. One can see what seem to be only aggregates of magnetic nanoparticles, with a size ranging from $100 \mathrm{~nm}$ 
to $200 \mathrm{~nm}$, coherent with the measured hydrodynamic diameter (197 $\pm 120 \mathrm{~nm}$, Figure $2 \mathrm{~d}$ ). The presence of the imprints does not seem to affect the size of the final nano-objects, as MIPand NIP-functionalized $\gamma-\mathrm{Fe}_{2} \mathrm{O}_{3}$ nanoparticles are very similar in size. High-resolution TEM evidenced an amorphous coating around these aggregates (see Figure 1c). Further analysis identified this amorphous coating as the polymer. Indeed, the size of the bare, MIPfunctionalized and NIP-functionalized maghemite nanoparticles were determined using dynamic light scattering, as presented on Figure $2 \mathrm{~d}$. The presence of the polymer around the magnetic nanoparticles induces a strong increase in the size of the final objects. Fourier Transform infrared (FTIR) spectra of bare, iniferter-functionalized and polymer-coated maghemite nanoparticles were also recorded (Figure 2c). Bare maghemite nanoparticles display peaks at $628 \mathrm{~cm}^{-1}$ and $580 \mathrm{~cm}^{-1}$ corresponding to the Fe-O vibration, while FTIR spectrum of iniferter-functionalized nanoparticles depicts new peaks around $2900 \mathrm{~cm}^{-1}$ and $1630 \mathrm{~cm}^{-1}$, corresponding respectively to the stretch and scissoring movements of C-H bonds. Thus, surface functionalization of maghemite was effective. A new peak appears around $1530 \mathrm{~cm}^{-1}$ on the FTIR spectrum of $\gamma-\mathrm{Fe}_{2} \mathrm{O}_{3} @ \mathrm{MIP}$ corresponding to $\mathrm{C}=\mathrm{O}$ vibrations of acrylamide, and the peak previously situated around $1630 \mathrm{~cm}^{-1}$ shifted toward higher wavenumbers values, suggesting that polymer was successfully synthesized. Moreover, $\gamma-\mathrm{Fe}_{2} \mathrm{O}_{3} @$ MIP displayed about 24\% weight-loss, much higher than what was observed for bare or iniferter functionalized nanoparticles ( $8 \%$ and $18 \%$ respectively, Figure $2 \mathrm{a}$ ), proving the existence of the organic part of the hybrid nanoparticles. $\gamma-\mathrm{Fe}_{2} \mathrm{O}_{3} @ \mathrm{MIP}$ before and after protein extraction clearly show a $10 \%$ weight-loss difference at temperatures ranging from 100 to $200{ }^{\circ} \mathrm{C}$ (Figure $2 \mathrm{~b}$ ). This corresponds to the loss of proteins and confirms the presence of imprints as well as the effectiveness of the extraction method used.
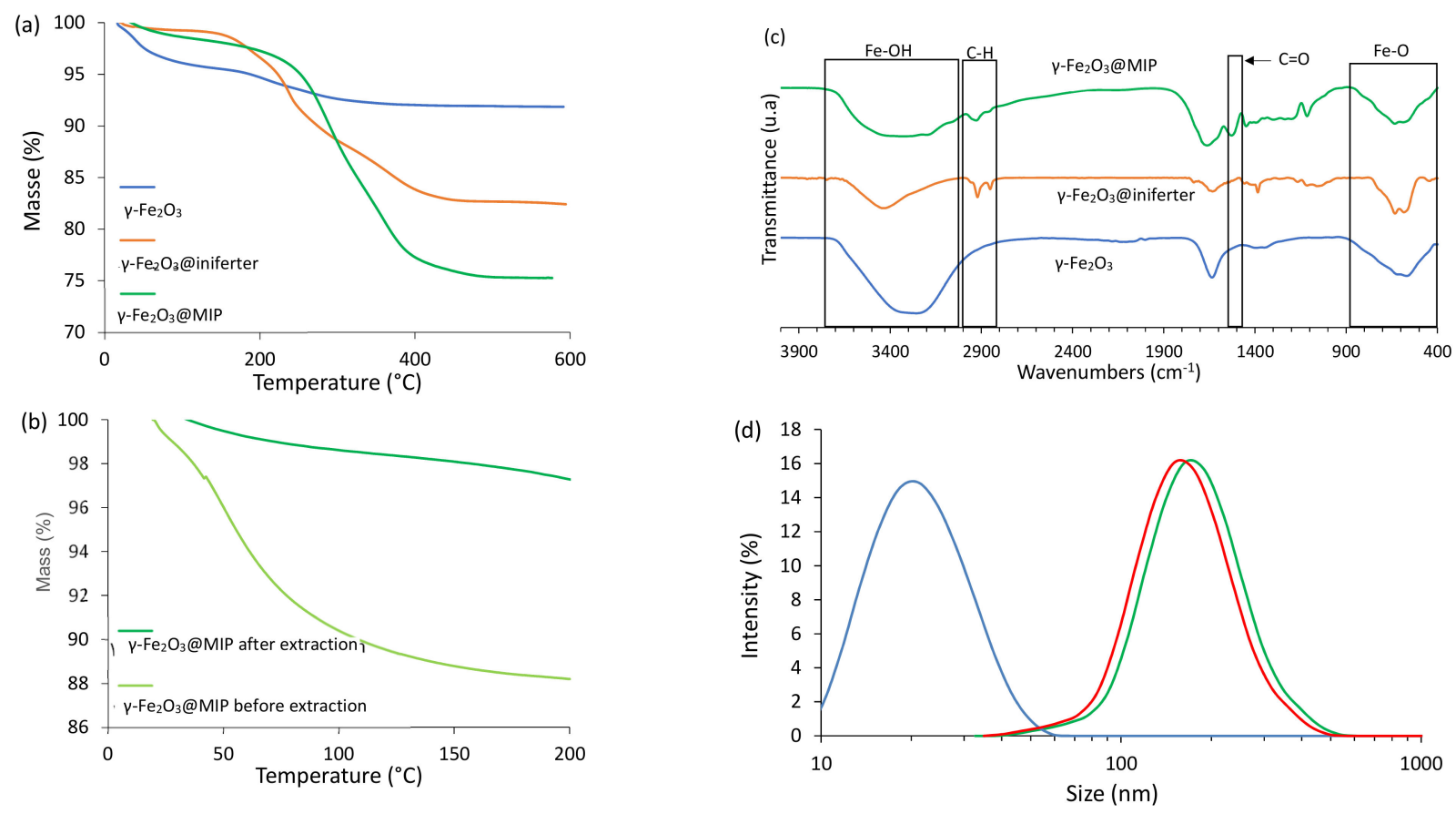

Figure 2. Characterizations of the different $\gamma-\mathrm{Fe}_{2} \mathrm{O}_{3}$ hybrid nano-objects. (a) TGA thermograms of bare, iniferterfunctionalized and MIP functionalized maghemite nanoparticles. (b) TGA thermograms of $\gamma-\mathrm{Fe}_{2} \mathrm{O}_{3} @ \mathrm{MIP}$ before and after protein extraction. (c) FTIR spectra of bare, iniferter-functionalized and MIP functionalized maghemite nanoparticles. (d): Dynamic light scattering profiles of bare (blue), MIP-functionalized $\gamma$ - $\mathrm{Fe}_{2} \mathrm{O}_{3}$ nanoparticles (green) and NIPfunctionalized $\gamma-\mathrm{Fe}_{2} \mathrm{O}_{3}$ nanoparticles (red).

Finally, in order to verify that maghemite nanoparticles remain magnetic while being coupled to the imprinted polymer, we sought to observe their response when submitted to a magnetic field. We prepared a water-in-oil emulsion, using egg-L- $\alpha$-phosphatidylcholine (EPC) as surfactant. An aqueous suspension of fluorescent $\gamma-\mathrm{Fe}_{2} \mathrm{O}_{3} @ \mathrm{MIP}(250 \mu \mathrm{L})$ was 
dispersed in $750 \mu \mathrm{L}$ of chloroform containing 1\% wt of EPC. After being well shaken, the emulsion was placed inside a capillary and observed using an optical microscope equipped a fluorescent source. The pictures presented in Figure $3 a, b$ were taken before and after the application of a magnetic field, created using a neodymium-ferrite-bore magnet. We can observe in Figure 3a that before application of the magnetic field, the drops are rather well dispersed in the capillary, and distant from each other. As the entire of volume of the drops is fluorescent, the hybrid nano-objects are stable within it. After approaching the magnet, many drops were attracted in the observed area (see Figure 3b). We can also observe that the smallest drops aligned, forming a chain in the direction of the magnetic field. Thus, $\gamma-\mathrm{Fe}_{2} \mathrm{O}_{3} @ \mathrm{MIP}$ nano-objects are able to respond to magnetic field, and polymer does not hinder the magnetism of the maghemite nanoparticles.
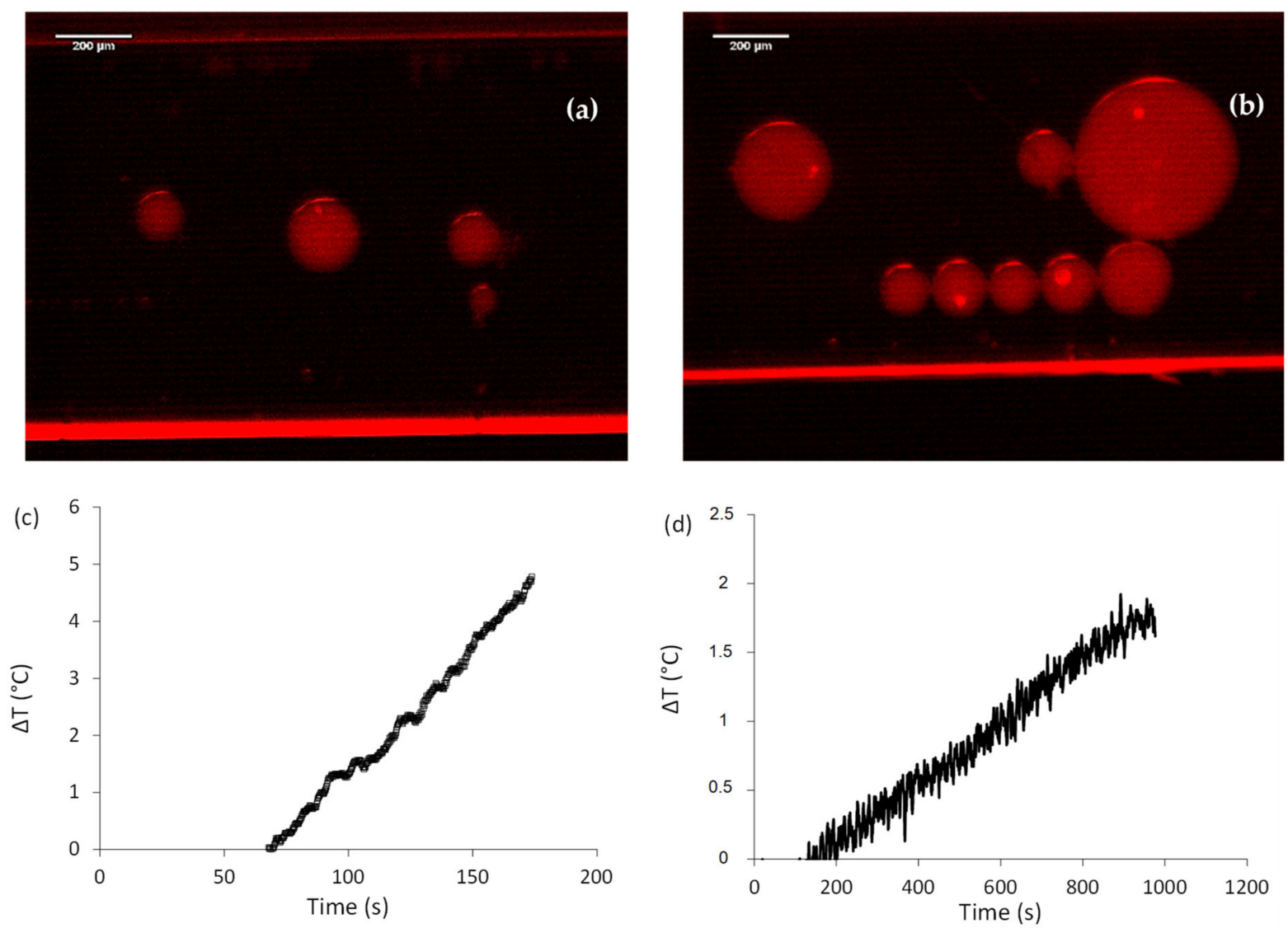

Figure 3. Magnetic characterizations of the different $\gamma-\mathrm{Fe}_{2} \mathrm{O}_{3}$ hybrid nano-objects. (a) Optic micrograph of a water-in-oil emulsion containing $\gamma-\mathrm{Fe}_{2} \mathrm{O}_{3} @ \mathrm{MIP}$ before application of a magnetic field, scale bar: $200 \mu \mathrm{m}$. (b) Optic micrograph of a water-in-oil emulsion containing $\gamma-\mathrm{Fe}_{2} \mathrm{O}_{3} @ \mathrm{MIP}$ after application of a magnetic field, scale bar: $200 \mu \mathrm{m}$. (c,d) Temperature increase of suspensions of bare (c) and MIP-functionalized (d) maghemite nanoparticles during the application of an alternating magnetic field at $335.1 \mathrm{kHz}, 9 \mathrm{mT}$ and $6 \mathrm{~A}$, after $60 \mathrm{~s}$ of equilibration at room temperature.

Magnetic properties were also assessed by measuring the temperature increase of dispersions containing bare or MIP-functionalized maghemite nanoparticles during the application of an alternating magnetic field at $335.1 \mathrm{kHz}, 9 \mathrm{mT}, 6 \mathrm{~A}$. When submitted to such a magnetic field, magnetic nanoparticles will dissipate energy by producing heat, which will produce a localized temperature increase. The increase of temperature recorded for both dispersions, containing either maghemite nanoparticles (Figure 3c) or hybrid nano-objects (Figure 3d) prove that maghemite nanoparticles have magnetic hyperthermia properties. However, as the temperature increase is higher when submitted bare magnetic nanoparticles to AMF compared to magnetic MIP nanoparticles (at the same iron oxide concentration), we conclude that the local heating of the particles does not easily diffuse 
beyond the hybrid material and that the heating property is maintained by nanoparticles embedded inside an imprinted polymer. Even if nanoparticles aggregation inside the polymer induces a diminution of their specific adsorption rate from $10.5 \mathrm{~W} / \mathrm{g}$ for bare nanoparticles to $6.2 \mathrm{~W} / \mathrm{g}$ for hybrid nano-objects [31,32], these properties are maintained, even once embedded inside the imprinted polymer.

The adsorption capacities of $\gamma-\mathrm{Fe}_{2} \mathrm{O}_{3} @ \mathrm{MIP}$ and $\gamma-\mathrm{Fe}_{2} \mathrm{O}_{3} @ \mathrm{NIP}$ were investigated by isothermal rebinding experiments. The adsorption capacities $(\mathrm{Q})$ of both magnetic protein imprinted and non-imprinted polymers were determined. The adsorption curves displayed on Figure 4 show that the amount of adsorbed proteins increased with the initial concentration of GFP before reaching equilibrium. MIP has a maximal adsorption capacity of $57.5 \mathrm{mg} / \mathrm{g}$, constant over eight adsorption-desorption cycles (Figure $4 \mathrm{~b}$ ) and adsorbs 2.28 times more GFP than the NIP. This confirms the existence of imprints and their efficiency to recognize the template protein.

(a)

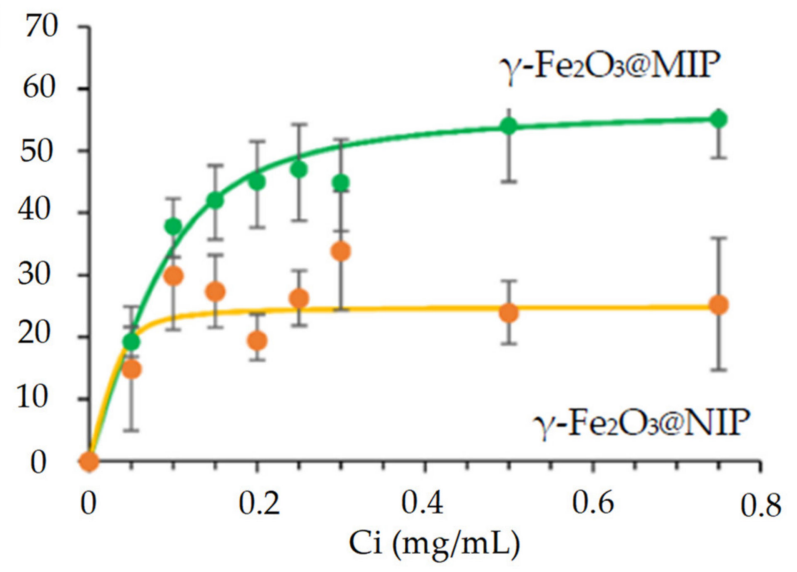

(b) 70

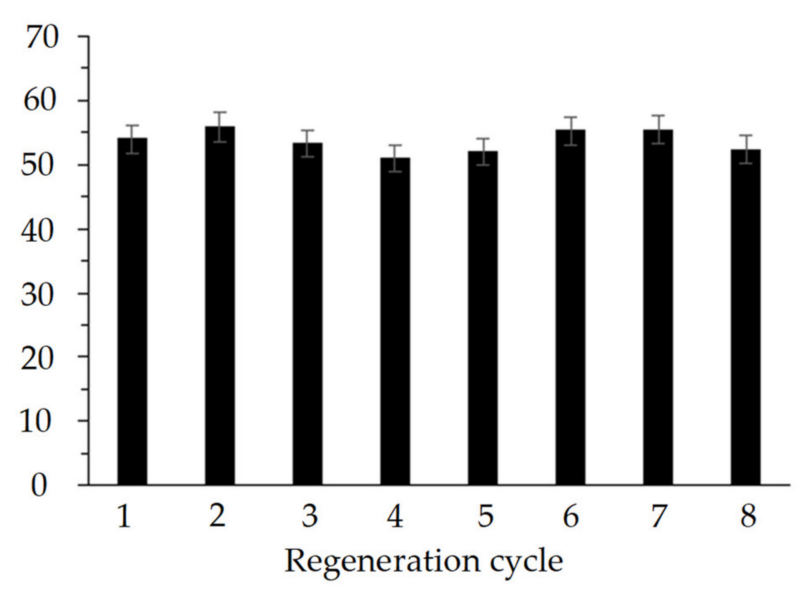

Figure 4. (a) Adsorption isotherms of GFP onto magnetic MIP and NIP, fitted with a Langmuir adsorption model, with $\mathrm{V}=3 \mathrm{~mL}, \mathrm{~m}=5 \mathrm{mg}, \mathrm{Ci}=0-0.75 \mathrm{mg} / \mathrm{mL}$, time: $2 \mathrm{~h}$. (b) Influence of the number of adsorption-desorption cycles on the adsorption capacity of $\gamma-\mathrm{Fe}_{2} \mathrm{O}_{3} @$ MIP-GFP. $\mathrm{V}=3 \mathrm{~mL}, \mathrm{~m}=5 \mathrm{mg}$ and $\mathrm{Ci}=0.5 \mathrm{mg} / \mathrm{mL}$ at room temperature.

To further investigate the protein-MIP interaction mechanism, a kinetic study was carried out. $\mathrm{k}_{1}$ is the pseudo-first order rate constant $\left(\mathrm{min}^{-1}\right), \mathrm{k}_{2}$ is the pseudo-second order rate constant $(\mathrm{g} / \mathrm{mg} / \mathrm{min})$. $Q_{e}$ and $Q_{t}$ are the amount of protein adsorbed $(\mathrm{mg} / \mathrm{g})$ at equilibrium or at time $t$, respectively.

A pseudo second-order kinetic model was deemed suitable to fit the experimental data than a pseudo 1st order (Figure 5 as well as Table 1), suggesting that GFP adsorption on magnetic MIP obeys to a controlled diffusion process.

Selective and competitive adsorption experiments were conducted using two nonfluorescent proteins with different isoelectric points and molecular weight (ovalbumin, OVA and lysozyme, Lyz) (Figure 6a). Magnetic GFP-imprinted polymers exhibit a higher recognition capacity toward GFP than OVA or Lyz, indicating that MIP have a much higher affinity for the template protein than for the competitive ones (Table S2). This may be due to the physical differences between them. OVA being bigger than GFP (Mw: $42.7 \mathrm{kDa}$ against $27 \mathrm{kDa}$ ), it should have difficulties diffusing inside the polymer and entering the imprints. And at $\mathrm{pH}=8$, Lyz is charged positively while imprints were designed to interact with negatively charged proteins. Moreover, imprinting factors closed to 1 for both Lyz and OVA (Table S2) confirm that the recognition cavities of the imprinted polymers play no role in the adsorption of these competitive proteins. Non-specific interactions between amide functions of the polymer and proteins are sole responsible and $\gamma-\mathrm{Fe}_{2} \mathrm{O}_{3} @ \mathrm{MIP}$ are selective toward GFP, a result confirmed by the good selectivity coefficients displayed (Figure $6 \mathrm{~b}$ and Table S2). The lower adsorption capacities of the $\gamma-\mathrm{Fe}_{2} \mathrm{O}_{3} @ \mathrm{MIP}$ nano-objects toward GFP in protein mixture 1 compared to the one single protein solution could be explained 
by a loss in the non-specific adsorption. Indeed, non-specific adsorption of Lyz or OVA will deprive the GFP of some non-specific adsorption sites.

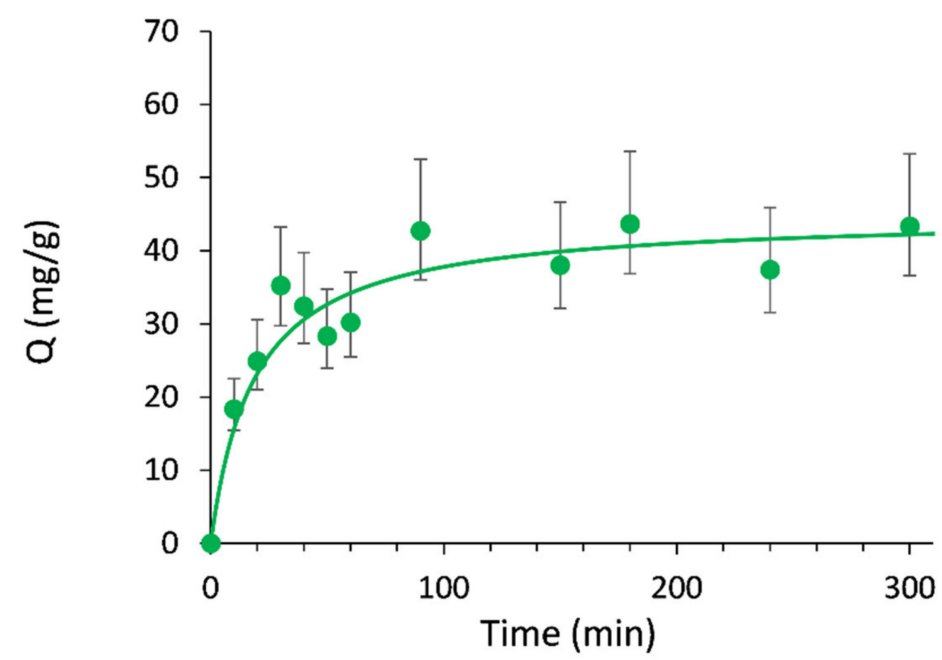

Figure 5. Adsorption kinetics of magnetic MIP toward GFP fitted with a pseudo-second order kinetic model, with $\mathrm{V}=3 \mathrm{~mL}, \mathrm{~m}=5 \mathrm{mg}, \mathrm{C}_{\mathrm{i}}=0.15 \mathrm{mg} / \mathrm{mL}$, time: $0-5 \mathrm{~h}$.

Table 1. Parameters of pseudo-first order and pseudo-second order adsorption kinetics models for GFP on $\gamma-\mathrm{Fe}_{2} \mathrm{O}_{3} @ \mathrm{MIP}$.

\begin{tabular}{ccccc}
\hline Adsorption Model & $\mathbf{R}$ & $\mathbf{Q}_{\mathrm{e}, \text { theo }}(\mathbf{m g} / \mathbf{g})$ & $\mathbf{Q}_{\mathbf{e}, \mathbf{e x p}}(\mathbf{m g} / \mathbf{g})$ & $\mathbf{k}$ \\
\hline Pseudo 1st order & 0.853 & 40.2 & 44.3 & $4.5 \times 10^{-2} \mathrm{~min}^{-1}$ \\
\hline Pseudo 2nd order & 0.978 & 44.8 & 44.3 & $1.19 \times 10^{-3} \mathrm{~g} / \mathrm{mg} / \mathrm{min}$ \\
\hline
\end{tabular}
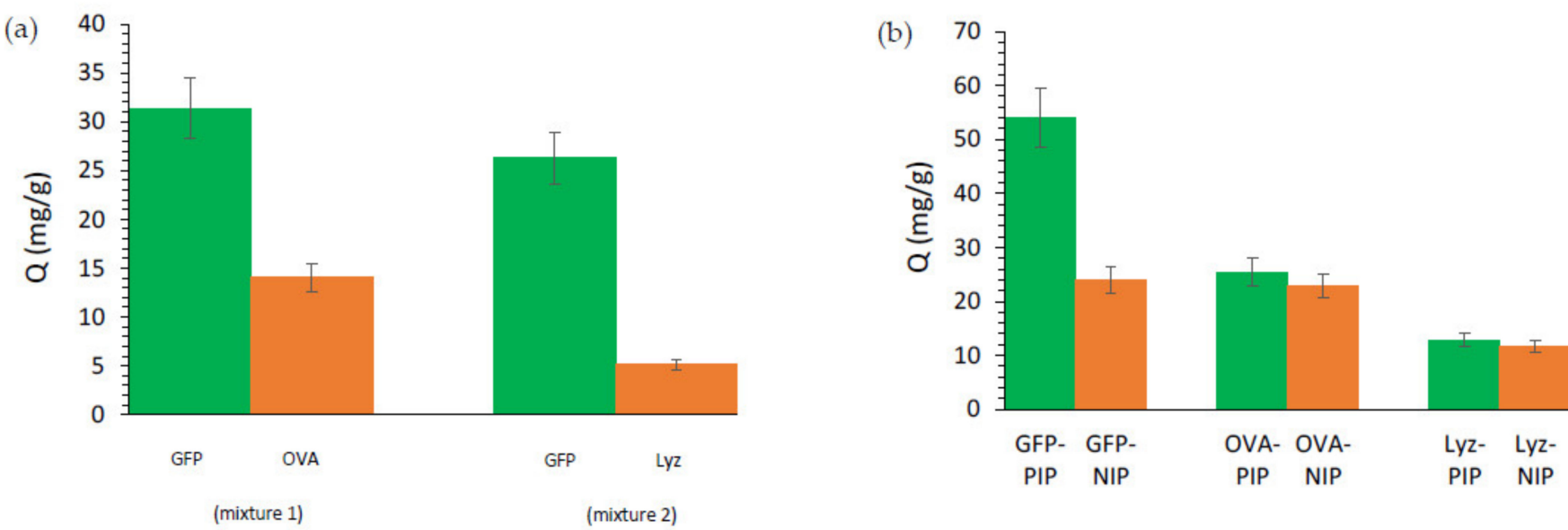

Figure 6. (a) Competitive adsorption tests performed on magnetic MIP with $5 \mathrm{mg}$ of $\gamma-\mathrm{Fe}_{2} \mathrm{O}_{3} @ \mathrm{MIP}$ dispersed in $3 \mathrm{~mL}$ of a double protein mixture solution, either GFP and OVA (mixture 1) or GFP and Lyz (mixture 2), each protein being present at a concentration of $0.5 \mathrm{mg} / \mathrm{mL}$, and shaken at room temperature for $2 \mathrm{~h}$. (b) Adsorption performances of $\gamma-\mathrm{Fe}_{2} \mathrm{O}_{3} @ \mathrm{MIP}$ and NIP nano-objects. $5 \mathrm{mg}$ of magnetic protein imprinted or non-imprinted polymer were added to $3 \mathrm{~mL}$ of HEPES buffer containing $0.5 \mathrm{mg} / \mathrm{mL}$ of reference proteins. The mixture was shaken at room temperature for two hours, to reach equilibrium.

We first looked at the passive desorption of GFP by dispersing $5 \mathrm{mg}$ of $\gamma-\mathrm{Fe}_{2} \mathrm{O}_{3} @ M I P$ in $3 \mathrm{~mL}$ of a GFP solution at $0.8 \mathrm{mg} / \mathrm{mL}$ and shaken continuously at room temperature for two hours, to reach adsorption equilibrium. Then, particles were collected using a permanent magnet, supernatant was removed, and the GFP-saturated nanoparticles were 
dispersed in $3 \mathrm{~mL}$ of HEPES buffer $(\mathrm{pH}=8,200 \mathrm{mM})$. Sample was shaken continuously at room temperature and supernatant was collected using magnetic decantation and analysed by UV-Visible spectroscopy from time to time to determine the quantity of free protein. The amount of GFP desorbed by the magnetic imprinted polymers oscillates between $0 \%$ and $6 \%$ (mean value of $2.8 \%$ ) of the maximal possible desorbable quantity, as displayed on Figure S1. Once GFP has been adsorbed by magnetic MIP, no significant passive desorption of trapped proteins occurs.

Then we investigated the effect of alternating magnetic field on the hybrid materials after GFP adsorption. The denaturation of GFP was investigated as follows, using the magnetic hyperthermia properties of maghemite nanoparticles. $5 \mathrm{mg}$ of $\mathrm{Fe}_{2} \mathrm{O}_{3} @ \mathrm{MIP}$ were first saturated with GFP as described above and dispersed in $3 \mathrm{~mL}$ of HEPES buffer $(\mathrm{pH}=8$, $200 \mathrm{mM}$ ). Sample was then placed in an Eppendorf tube inside the coil of a MagneTherm system, and an alternating magnetic field was applied for 5 to $45 \mathrm{~min}$ at different magnetic field $(3.35 \mathrm{mT}, 6.7 \mathrm{mT}, 10 \mathrm{mT}$ and $13.4 \mathrm{mT})$. Before and after application of the magnetic pulse, the magnetic suspension was directly analysed using fluorescence spectroscopy to determine the protein fluorescence loss (difference between the fluorescence before application and after AMF application). Protein denaturation experiment using alternating magnetic field was also carried out for a solution of GFP at $0.29 \mathrm{mg} / \mathrm{mL}$ in HEPES, $\mathrm{pH}=8$, $200 \mathrm{mM}$, without magnetic nanoparticles.

When we apply AMF on magnetic MIP containing GFP, the direct analysis of the fluorescent intensity decreases which is correlated to a modification of the GFP threedimensional structure. Additionally, even if the magnetic field increases, the fluorescence loss of GFP is the same. This could be explained by the local heating temperature of the magnetic nanoparticles leading to the denaturation of the proteins that are near to the magnetic cores, and those who are far are not heated and not denatured. Moreover, the GFP alone in solution does not seem to undergo an as significant denaturation (labeled GFP bulk on Figure 7A), although it remains sensitive to the applied AMF. Thus, the fluorescence loss measured for proteins adsorbed by the hybrid nano-objects, and therefore their denaturation, seems to be due to the temperature increase induced by hyperthermia, and not only by the magnetic field itself.

Then, we looked at the duration effect of the AMF application on the GFP denaturation. As we can see on Figure 7B, even if we apply AMF during $45 \mathrm{~min}$ at $3.35 \mathrm{mT}$, the GFP fluorescence intensity lost does not exceed $60 \%$ obtained after $15 \mathrm{~min}$ of AMF application. As the results obtained with the magnetic field increase, the adsorbed GFP proteins not near to the magnetic nanoparticles cannot feel the locally temperature increase under AMF even if we increase the duration of AMF until $45 \mathrm{~min}$.

The heat-triggered desorption of GFP was investigated as follows, using the magnetic hyperthermia properties of maghemite nanoparticles. $5 \mathrm{mg}$ of $\mathrm{Fe}_{2} \mathrm{O}_{3} @ \mathrm{MIP}$ were first saturated with GFP as described above and dispersed in $3 \mathrm{~mL}$ of HEPES buffer $(\mathrm{pH}=8$, $200 \mathrm{mM}$ ). Sample was then placed in an Eppendorf tube inside the coil of a MagneTherm system, and an alternating magnetic field was applied for $15 \mathrm{~min}$ at at $335.1 \mathrm{kHz}, 9 \mathrm{mT}$ and various intensities. Afterwards, supernatant was collected using magnetic decantation and analysed using UV-Visible spectroscopy to determine the quantity of desorbed protein. GFP-desorption after AMF application (Figure S1) at various intensities (in Amper) is slow (only 3\% of GFP is desorbed whatever the intensity of AMF that is applied). The local temperature increase upon AMF should disrupt hydrogen bonding and should lead to protein desorption, but it seems that application of an AMF was not able to induce GFP desorption. This could be due to the big size of the protein that cannot diffuse inside the polymer pores existing in the MIP. As the desorption of the denatured protein does not occur, the effect of the adsorption of intact protein and the desorption of the denatured protein is limited because only small amount of adsorbed protein is inhibited and finally release. However, for in vivo applications of this protein denaturation method, to stop the proliferation of cancer cells for example, if the material is degraded in vivo at the tumor 
site, finally the denatured free protein won't be recognized by the cancer cells and hence will limit the cancer cell propagation.
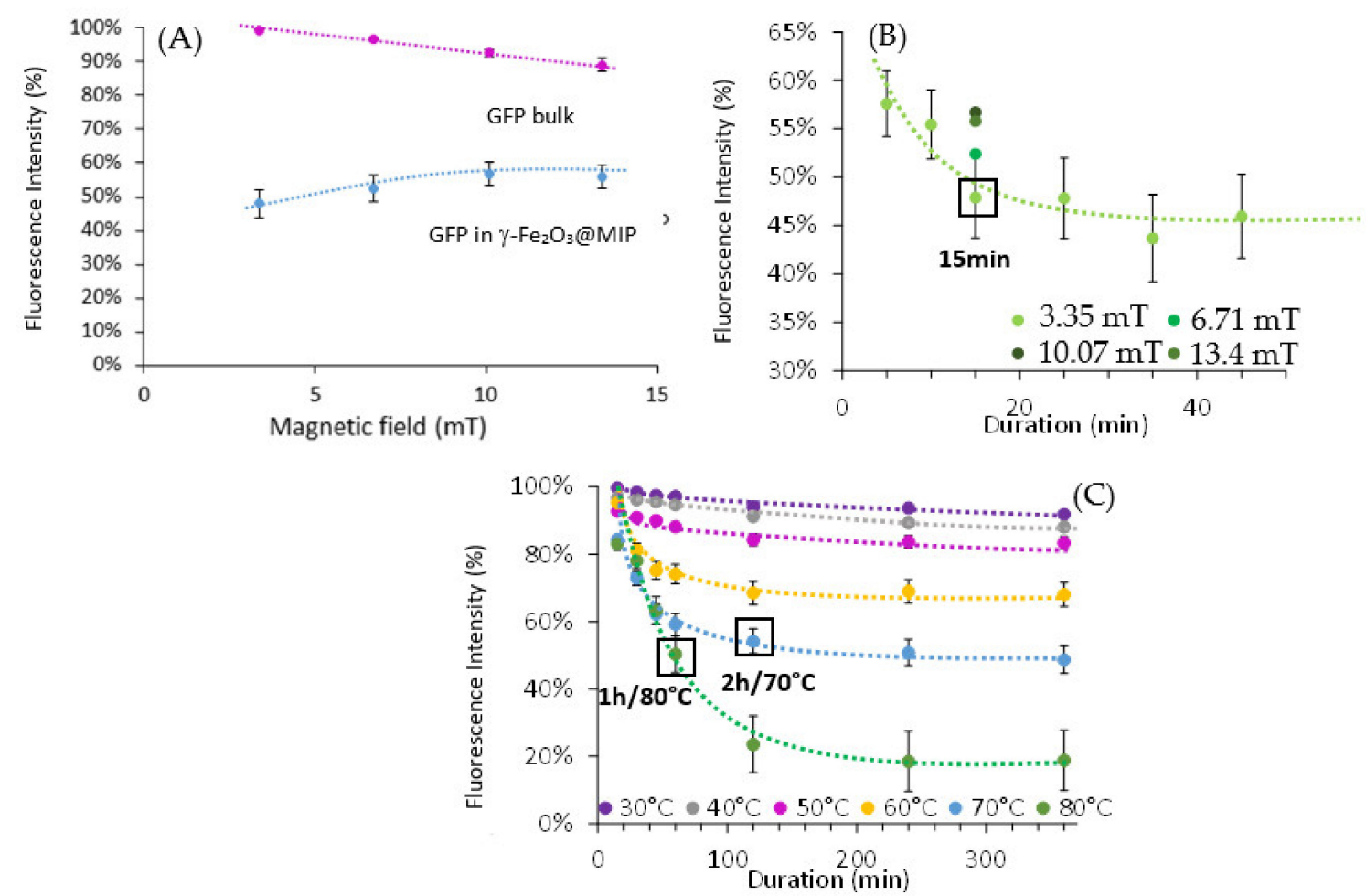

Figure 7. GFP denaturation experiments, with $\mathrm{V}=3 \mathrm{~mL}, \mathrm{~m}=5 \mathrm{mg}\left(\left[\gamma-\mathrm{Fe}_{2} \mathrm{O}_{3}\right]: 8 \mathrm{mmol} / \mathrm{L}\right.$, (A) using magnetic hyperthermia (AMF at $335.1 \mathrm{kHz}$ and various intensities) for $15 \mathrm{~min}$, (B) in function of the time, (C) using different temperature and duration.

As any macroscopic temperature increase occurs when applying AMF, we decided to determine the temperature felt by the GFP when applying AMF leading to $45 \%$ of fluorescence loss after the application of AMF during $15 \mathrm{~min}$ at $3.35 \mathrm{mT}$. Hence, magnetic nanoparticles containing GFP were heated at temperature between 30 and $80^{\circ} \mathrm{C}$ during $15 \mathrm{~min}$ to $6 \mathrm{~h}$ (Figure 7C). We can see that a significant fluorescent intensity loss appears if the heating is above $50^{\circ} \mathrm{C}$. If we compare the GFP fluorescence intensity when applying $15 \mathrm{~min}$ of AMF at $3.35 \mathrm{mT}$ it seems to be equivalent to heating the particles at $70{ }^{\circ} \mathrm{C}$ during $2 \mathrm{~h}$ or at $80^{\circ} \mathrm{C}$ during $1 \mathrm{~h}$. When the particles heat upon AMF, the proteins near to the magnetic core are directly and quickly denatured. When the heating is performed, the time required to have the global good temperature for the protein denaturation may be longer. Moreover, in this case the denaturation occurs on all the proteins that is not the case when using AMF, apparently only the proteins near to the magnetic cores have a decrease of their fluorescent intensity and are inhibited. This could explain the difference obtained in the duration needed to have the equivalent loss of fluorescent upon AMF and when they are heated.

\section{Materials and Methods}

\subsection{Materials}

Ovalbumin (OVA), lysozyme (Lyz), acrylamide (AM), N,N-methylene-bis-acrylamide (MBAM), ammonium persulfate (APS), $\mathrm{N}, \mathrm{N}, \mathrm{N}^{\prime}, \mathrm{N}^{\prime}$-tertramethylethylenediamine (TEMED), 4-(2-hydroxyethyl)-1-piperazine-ethanesulfonic acid (HEPES), phosphate-buffered saline (PBS), 4-cyano-4-[(dodecylsulfanylthiocarbonyl)sulfanyl] pentanoic acid (iniferter agent), paraformaldehyde, Dulbecco's modified Eagle's medium with nutriment mixture F12 (DMEM/F12), fetal bovine serum (FBS), and PenStrep were provided by Sigma-Aldrich 
(Molsheim, France). Iron (II) chloride tetrahydrate $\left(\mathrm{FeCl}_{2} \cdot 4 \mathrm{H}_{2} \mathrm{O}\right)$, iron (III) chloride hexahydrate $\left(\mathrm{FeCl}_{3} \cdot 6 \mathrm{H}_{2} \mathrm{O}\right)$, iron (III) nitrate nonahydrate $\left(\mathrm{Fe}\left(\mathrm{NO}_{3}\right)_{3} \cdot 9 \mathrm{H}_{2} \mathrm{O}\right)$, acetone, diethyl ether, ethanol at $96 \%$, chloroform and methanol were provided by VWR Chemicals (Lutterworth, UK). Ammonia solution $\left(\mathrm{NH}_{3} ; 20 \%\right)$ and acetic acid were provided by Carlo Erba (Val-de-Reuil, France). Hydrochloric acid was provided by Merck (Molsheim, France). Acryloxyethylthiocarbamoyl-Rhodamine B was purchased from Polysciences, Inc. (Nanterre, France) The green fluorescent protein (GFP) was kindly provided to us by the Dahan group of the Curie Research Institute (Paris, France). All materials were used as received without any purification.

\subsection{Characterization}

Fourier Transform infrared (FTIR) spectra were recorded on a Tensor 27 spectrophotometer (Bruker, Palaiseau, France) in a KBr matrix. Thermogravimetric analysis (TGA) were carried out for bare maghemite nanoparticles and polymer coated nanoparticles using a SDT-Q600 system (TA Instruments, New Castle, DE, USA) under a nitrogen atmosphere with a heating rate of $10^{\circ} \mathrm{C} / \mathrm{min}$ up to $600{ }^{\circ} \mathrm{C}$. Hydrodynamic diameters were measured at $25^{\circ} \mathrm{C}$ using a Zetasizer Nano series (Malvern Instruments, Orsay, France). Images of the nano-objects were taken using an either a JEOL-100 CX transmission electron microscope (TEM) or a JEOL 2100F microscope (high resolution transmission electron microscopy, HRTEM) (JEOL, Croissy, France), and carbon-coated copper grids. UV-Vis adsorption spectra were recorded on an UVIKON XL spectrophotometer (SECOMAM, Champignysur-Marne, France). Measurements of protein fluorescence were performed using a Varian Cary Eclipse fluorescence spectrophotometer (Agilent, Agilent, France).

The specific adsorption rate (SAR) measurements of bare and MIP-functionalized maghemite nanoparticles and the adsorbed GFP denaturation experiments were carried out with a MagneTherm system (Nanotherics, Warrington, UK) equipped with a fluoroptic fiber thermometer. The sample was at room temperature before the application of an alternating magnetic field $(335.1 \mathrm{kHz}, 3.35-13.4,5$ or $15 \mathrm{~min})$.

The SAR was calculated using Equation (1) after having fitted the experimental curves (temperature increase as a function of time) using the Box-Lucas equation presented as Equation (2):

$$
\begin{gathered}
\mathrm{SAR}=\mathrm{A} \cdot \lambda \cdot \frac{\mathrm{C}_{\mathrm{p}}}{\mathrm{C}_{\mathrm{m}}} \\
\Delta \mathrm{T}=\mathrm{A}\left(1-\mathrm{e}^{\lambda\left(\mathrm{t}-\mathrm{t}_{0}\right)}\right)
\end{gathered}
$$

where $\Delta \mathrm{T}$ is the temperature variation, $\mathrm{A}$ and $\lambda$ are experimental constants known as the Box-Lucas' constants obtained by fitting the experimental curve, $\mathrm{t}_{0}$ is the moment the AMF was applied, $\mathrm{C}_{\mathrm{m}}$ is the mass concentration of iron oxide nanoparticles $(1.65 \% \mathrm{wt}$; polymer is neglected) and $C_{p}$ is the heat capacity of the solution $(4.12 \mathrm{~J} / \mathrm{g} / \mathrm{K}$ to consider both water and magnetic nanoparticles at the specified $C_{m}$ ).

\subsection{Synthesis of Functionalized Magnetic Nanoparticles}

Maghemite nanoparticles were synthesized using a co-precipitation method as previously described by Massart [1]. Briefly, ferrous chloride (180 g) and ferric chloride (1.59 mol) were dissolved in $6 \%$ hydrochloric acid. Ammonia ( $1 \mathrm{~L}, 22.5 \%$ ) was added to the mixture under vigorous magnetic stirring at room temperature. The reaction was allowed to proceed for $30 \mathrm{~min}$. Then, the as-obtained magnetite was oxidized using ferric nitrate ( $323 \mathrm{~g}$ ). The suspension was heated at $100{ }^{\circ} \mathrm{C}$ under magnetic stirring for $30 \mathrm{~min}$. Maghemite nanoparticles were then washed three times with acetone and two times with diethyl ether, before being dispersed in water.

The surface of the nanoparticles was directly functionalized with an iniferter agent, using a protocol slightly modified from the one of Gonzato et al. [2]. In short, the iniferter agent, 4-cyano-4-[(dodecylsulfanylthiocarbonyl)sulfanyl]pentanoic acid $(60 \mathrm{mg})$ was dissolved in ethanol $(4 \mathrm{~mL}, 96 \%)$, followed by the addition of distilled water $(26 \mathrm{~mL})$ and 
$\gamma-\mathrm{Fe}_{2} \mathrm{O}_{3}$ nanoparticles $(500 \mathrm{mg}$ ). The reaction was allowed to proceed at room temperature for $18 \mathrm{~h}$ under continuous orbital stirring. Then, functionalized nanoparticles were dialyzed using a $5 / 5$ water/ethanol at $96 \%$ mixture until no more molecules were detected by conductivity measurements.

\subsection{Synthesis of $\gamma-\mathrm{Fe}_{2} \mathrm{O}_{3} @ M I P$}

The synthesis of imprinted polymers was carried out as previously described [3]. Briefly, GFP $(10 \mu \mathrm{mol})$ and acrylamide $(30 \mathrm{mmol})$ were dissolved in HEPES buffer $(150 \mathrm{~mL}$, $200 \mathrm{mM}, \mathrm{pH}=8$ ). The mixture was allowed to react and form a pre-polymerization complex for $2 \mathrm{~h}$ at room temperature under constant magnetic stirring. Then, $\mathrm{N}, \mathrm{N}-$ methylene-bisacrylamide ( $3 \mathrm{mmol})$, acryloxyethylthiocarbamoyl-Rhodamine B $(0.6 \mathrm{mmol})$, functionalized nanoparticles $(300 \mathrm{mg}$ ) and APS $(25 \mathrm{mg})$ were added and the mixture was nitrogen purged for 15 min under magnetic stirring. Lastly, TEMED $(75 \mu \mathrm{L})$ was added to the mixture and the reaction was allowed to proceed for $18 \mathrm{~h}$ at room temperature under magnetic stirring. The final product was washed and template proteins were extracted using dialysis until no more fluorescence remains in the solution and no more proteins or molecules were detected by conductivity measurements. Dialysis baths were alternatively composed of a 5/4/1 water/methanol/acetic acid mixture and distilled water. Finally, particles were transferred into HEPES buffer $(200 \mathrm{mM}, \mathrm{pH}=8)$. Non-imprinted polymers (NIP) were synthetized using the same way but without the GFP as template.

\subsection{In Vitro Adsorption Performances}

The adsorption kinetics of $\gamma$ - $\mathrm{Fe}_{2} \mathrm{O}_{3} @$ MIP were investigated as follows: $\gamma-\mathrm{Fe}_{2} \mathrm{O}_{3} @ \mathrm{MIP}$ $(5 \mathrm{mg})$ were dispersed in a GFP solution $(3 \mathrm{~mL}, 0.15 \mathrm{mg} / \mathrm{mL})$ and shaken continuously at room temperature. Analyses were performed at certain pre-determined intervals, consisting in the collection of particles by an external magnetic field and analyse of supernatants using UV-visible spectroscopy and the excitation peak at $488 \mathrm{~nm}$. The spectroscopy results allowed the assessment of the remaining concentration of protein and the determination of the quantity of adsorbed GFP, according to Equation (3):

$$
\mathrm{Q}=\frac{\left(\mathrm{C}_{\mathrm{i}}-\mathrm{C}_{\mathrm{f}}\right) \mathrm{V}}{\mathrm{m}}
$$

where $C_{i}(\mathrm{mg} / \mathrm{mL})$ and $C_{f}(\mathrm{mg} / \mathrm{mL})$ are respectively the initial and final concentrations of the protein samples, determined using UV-Visible spectroscopy, $\mathrm{V}(\mathrm{mL})$ is the volume of the protein solution and $\mathrm{m}(\mathrm{mg})$ is the mass of hybrid nano-objects in suspension.

The pseudo-first order kinetic model (Equation (4)) and the pseudo second-order kinetic model (Equation (5)) were used to fit the data.

$$
\begin{gathered}
\mathrm{Q}_{\mathrm{t}}=\mathrm{Q}_{\mathrm{e}}\left[1-\mathrm{e}^{-\mathrm{k}_{1} \mathrm{t}}\right] \\
\frac{\mathrm{t}}{\mathrm{Q}_{\mathrm{t}}}=\frac{\mathrm{t}}{\mathrm{Q}_{\mathrm{e}}}+\frac{1}{\mathrm{k}_{2} \mathrm{Q}_{\mathrm{e}}^{2}}
\end{gathered}
$$

where $\mathrm{k}_{1}$ is the pseudo-first order rate constant $\left(\mathrm{min}^{-1} \mathrm{~J}\right), \mathrm{k}_{2}$ is the pseudo-second order rate constant $(\mathrm{g} / \mathrm{mg} / \mathrm{min})$. $Q_{e}$ and $Q_{t}$ are the amount of protein adsorbed $(\mathrm{mg} / \mathrm{g})$ at equilibrium or at time $t$ respectively.

The adsorption capacities $(Q)$ of both magnetic protein imprinted and non-imprinted polymers were determined using the following protocol. $\gamma-\mathrm{Fe}_{2} \mathrm{O}_{3} @ \mathrm{MIP}$ or NIP $(5 \mathrm{mg})$ were dispersed in protein solutions $(3 \mathrm{~mL})$ at different initial concentrations. The resulting mixtures were shaken at room temperature for two hours. As previously described, particles were collected using an external magnetic field and supernatants were analysed using UV-Visible spectroscopy to determine the adsorption capacity according to Equation (3). 
The adsorption of GFP on both $\gamma-\mathrm{Fe}_{2} \mathrm{O}_{3} @ \mathrm{MIP}$ and $\gamma-\mathrm{Fe}_{2} \mathrm{O}_{3} @ \mathrm{NIP}$ could be fitted using two different adsorption models. The first one is the Langmuir adsorption model (Equation (6)) and the second one is the Freundlich model (Equation (7)):

$$
\begin{gathered}
\frac{\mathrm{C}_{\mathrm{e}}}{\mathrm{Q}_{\mathrm{e}}}=\frac{\mathrm{C}_{\mathrm{e}}}{\mathrm{Q}_{\max }}+\frac{1}{\mathrm{~K}_{\mathrm{L}} \mathrm{Q}_{\max }} \\
\mathrm{Q}_{\mathrm{e}}=\mathrm{K}_{\mathrm{F}} \mathrm{C}_{\mathrm{e}}^{1 / \mathrm{m}}
\end{gathered}
$$

where $C_{e}$ is the equilibrium concentration of GFP in solution $(\mathrm{mg} / \mathrm{mL}), \mathrm{Q}_{\mathrm{e}}$ is the equilibrium amount of adsorbed GFP $(\mathrm{mg} / \mathrm{g}), \mathrm{Q}_{\max }$ is the theoretical maximal amount of adsorbed GFP $(\mathrm{mg} / \mathrm{g}), \mathrm{K}_{\mathrm{L}}$ is the Langmuir constant $(\mathrm{mL} / \mathrm{mg}$ ) related to the affinity of the adsorption sites, $\mathrm{K}_{\mathrm{F}}\left((\mathrm{mg} / \mathrm{g})(\mathrm{mL} / \mathrm{mg})^{\mathrm{m}}\right)$ is the Freundlich coefficient and $\mathrm{m}$ is the heterogeneity index.

OVA and Lyz were employed as reference proteins to determine the selectivity of $\gamma-\mathrm{Fe}_{2} \mathrm{O}_{3} @$ MIP toward GFP. Magnetic protein imprinted or non-imprinted polymer (5 mg) were added to HEPES buffer $(3 \mathrm{~mL})$ containing reference proteins $(0.5 \mathrm{mg} / \mathrm{mL})$. The mixture was shaken at room temperature for two hours, to reach equilibrium. Then, particles were collected, supernatant was analysed using UV-Vis spectroscopy and the absorption peak at $290 \mathrm{~nm}$ for OVA and Lyz, and the quantity of adsorbed protein was determined using Equation (3).

To further investigate the selectivity of $\gamma-\mathrm{Fe}_{2} \mathrm{O}_{3} @ \mathrm{MIP}$ toward GFP, competitive binding assays were carried out. Experiments were performed as follows: $\gamma-\mathrm{Fe}_{2} \mathrm{O}_{3} @ \mathrm{MIP}(5 \mathrm{mg})$ were dispersed in a double protein mixture solution $(3 \mathrm{~mL})$, either GFP and OVA (mixture 1) or GFP and Lyz (mixture 2), each protein being present at a concentration of $0.5 \mathrm{mg} / \mathrm{mL}$, and shaken at room temperature for $2 \mathrm{~h}$. Then, particles were collected, and supernatants were analysed using UV-Vis spectroscopy. GFP remaining concentration was determined using the absorption peak at $488 \mathrm{~nm}$, and contribution of GFP to the absorption peak at $290 \mathrm{~nm}$ was removed before determining the remaining concentration of the competitive protein. Quantities of adsorbed proteins were determined using Equation (3).

The imprinting factor (IF) and selectivity coefficient (SC) were calculated using Equations (8) and (9), were $\mathrm{Q}_{\mathrm{MIP}}$ and $\mathrm{Q}_{\mathrm{NIP}}(\mathrm{mg} / \mathrm{g})$ are the adsorption capacities of magnetic protein imprinted or non-imprinted polymers toward GFP, and $\mathrm{IF}_{\mathrm{t}}$ and $\mathrm{IF}_{\mathrm{c}}$ are the imprinting factors for the template protein and the reference protein, respectively.

$$
\begin{gathered}
\mathrm{IF}=\frac{\mathrm{Q}_{\mathrm{MIP}}}{\mathrm{Q}_{\mathrm{NIP}}} \\
S \mathrm{C}=\frac{\mathrm{IF}_{\mathrm{t}}}{\mathrm{IF}_{\mathrm{C}}}
\end{gathered}
$$

All experiments were carried out in HEPES buffer solution at $200 \mathrm{mM}$ and $\mathrm{pH}=8$.

\subsection{Reusability of $\gamma-\mathrm{Fe}_{2} \mathrm{O}_{3} @ M I P$}

After having adsorbed GFP, $\gamma-\mathrm{Fe}_{2} \mathrm{O}_{3} @ \mathrm{MIP}$ were eluted using alternatively a 9/1 methanol/acetic acid mixture and distilled water to remove proteins. After extraction, the regenerated $\gamma-\mathrm{Fe}_{2} \mathrm{O}_{3} @ \mathrm{MIP}$ were reused for next adsorption of GFP.

\subsection{Fate of Trapped Proteins}

The passive desorption of GFP was investigated as follows: $\gamma-\mathrm{Fe}_{2} \mathrm{O}_{3} @ \mathrm{MIP}$ (5 mg) were dispersed in a GFP solution $(3 \mathrm{~mL}, 0.8 \mathrm{mg} / \mathrm{mL})$ and shaken continuously at room temperature for two hours, to reach adsorption equilibrium. Then, particles were collected using a permanent magnet, supernatant was removed, and the GFP-saturated nanoparticles were dispersed in HEPES buffer $(3 \mathrm{~mL}, \mathrm{pH}=8,200 \mathrm{mM})$. Sample was shaken continuously at room temperature and supernatant was collected using magnetic decantation and analysed by UV-Visible spectroscopy from time to time to determine the quantity of free protein. 
The heat-triggered desorption and denaturation of GFP was investigated as follows, using the magnetic hyperthermia properties of maghemite nanoparticles. $\gamma-\mathrm{Fe}_{2} \mathrm{O}_{3} @ \mathrm{MIP}$ $(5 \mathrm{mg})$ were first saturated with GFP as described above, and dispersed in HEPES buffer ( $3 \mathrm{~mL}, \mathrm{pH}=8,200 \mathrm{mM}$ ). The sample was then placed in an Eppendorf tube inside the coil of a MagneTherm system, and an alternating magnetic field was applied for $15 \mathrm{~min}$ $(335.1 \mathrm{kHz})$. After application of the magnetic pulse, suspension was analysed using fluorescence spectroscopy to determine the protein fluorescence loss. Protein denaturation experiment using alternating magnetic field was also carried out for a solution of GFP $(0.29 \mathrm{mg} / \mathrm{mL})$ in HEPES $(\mathrm{pH}=8,200 \mathrm{mM})$, without magnetic nanoparticles.

Afterwards, supernatant was collected using magnetic decantation and analysed using UV-Visible spectroscopy to determine the quantity of desorbed protein. As heating could denature the GFP and modify its fluorescence properties, we did not use the absorption peak at $488 \mathrm{~nm}$, but the one at $285 \mathrm{~nm}$ for UV-visible spectroscopy measurements.

\section{Conclusions}

In conclusion, we have developed a new tool to specifically target proteins by means of magnetic molecularly imprinted polymers, prepared using iniferter-functionalized maghemite nanoparticles and polyacrylamide. Evaluation of the adsorption performances showed that $\gamma-\mathrm{Fe}_{2} \mathrm{O}_{3} @$ MIP displays relatively fast adsorption kinetics, good specificity and selectivity, and great recyclability. Polymers exhibit a great affinity toward GFP, as no significant passive or heat-induced desorption occurred. Finally, $\gamma-\mathrm{Fe}_{2} \mathrm{O}_{3} @ \mathrm{MIP}$ were employed to successfully denature targeted proteins, displaying a great potential for medical applications and the inhibition of the protein function.

Supplementary Materials: The following are available online, Table S1: Parameters of isotherm models for GFP adsorption on both $\gamma-\mathrm{Fe}_{2} \mathrm{O}_{3} @ \mathrm{MIP}$ and $\gamma-\mathrm{Fe}_{2} \mathrm{O}_{3} @ \mathrm{NIP}$, Table S2: Recognition selectivity of magnetic imprinted and non-imprinted nano-objects toward different proteins, Figure S1: GFPdesorption after heating of protein-saturated $\gamma-\mathrm{Fe}_{2} \mathrm{O}_{3} @ \mathrm{MIP}$ nano-objects for 15 min using magnetic hyperthermia (alternating magnetic field at $335.1 \mathrm{kHz}, 9 \mathrm{mT}$ and various intensities).

Author Contributions: Conceptualization, N.G. and C.M.; methodology, C.B., N.G. and C.M.; software, C.B.; validation, C.B.; formal analysis, C.B. and A.M.; investigation, C.B.; resources, C.B.; data curation, C.B.; writing-original draft preparation, C.B., N.G., C.M.; writing-review and editing, N.G.; visualization, N.G.; supervision, N.G. and C.M.; All authors have read and agreed to the published version of the manuscript.

Funding: This research received no external funding.

Conflicts of Interest: The authors declare no conflict of interest.

\section{References}

1. Butz, K.; Denk, C.; Ullmann, A.; Scheffner, M.; Hoppe-Seyler, F. Induction of apoptosis in human papillomaviruspositive cancer cells by peptide aptamers targeting the viral E6 oncoprotein. Proc. Natl. Acad. Sci. USA 2000, 97, 6693-6697. [CrossRef]

2. Farokhzad, O.C.; Jon, S.; Khademhosseini, A.; Tran, T.N.T.; La Van, D.A.; Langer, R. Nanoparticle-aptamer bioconjugates: A new approach for targeting prostate cancer cells. Cancer Res. 2004, 64, 7668-7672. [CrossRef] [PubMed]

3. Van de Broek, B.; Devoogdt, N.; D’Hollander, A.; Gijs, H.-L.; Jans, K.; Lagae, L.; Muyldermans, S.; Maes, G.; Borghs, G. Specific Cell Targeting with Nanobody Conjugated Branched Gold Nanoparticles for Photothermal Therapy. ACS Nano 2011, 5, 4319-4328. [CrossRef]

4. Rothbauer, U.; Zolghadr, K.; Tillib, S.; Nowak, D.; Schermelleh, L.; Gahl, A.; Backmann, N.; Conrath, K.; Muyldermans, S.; Cardoso, M.C.; et al. Targeting and tracing antigens in live cells with fluorescent nanobodies. Nat. Methods 2006, 3, 887-889. [CrossRef]

5. Ghahroudi, M.A.; Desmyter, A.; Wyns, L.; Hamers, R. Muyldermans, Selection and identification of single domain antibody fragments from camel heavy-chain antibodies. FEBS Lett. 1997, 414, 521-526. [CrossRef]

6. Vaneycken, I.; Devoogdt, N.; Van Gassen, N.; Vincke, C.; Xavier, C.; Wernery, U.; Muyldermans, S.; Lahoutte, T.; Caveliers, V. Preclinical screening of anti-HER2 nanobodies for molecular imaging of breast cancer. FASEB J. 2011, 25, 2433-2446. [CrossRef] [PubMed]

7. Li, S.; Xu, H.; Ding, H.; Huang, Y.; Cao, X.; Yang, G.; Li, J.; Xie, Z.; Meng, Y.; Li, X.; et al. Identification of an aptamer targeting hnRNP A1 by tissue slide-based SELEX. J. Pathol. 2009, 218, 327-336. [CrossRef] 
8. Workman, P.; Brunton, V.G.; Robins, D.J. Tyrosine kinase inhibitors. Semin. Cancer Biol. 1992, 3, 369-381.

9. McKenney, J.M.; Davidson, M.H.; Shear, C.L.; Revkin, J.H. The frequency and incremental cost of major complications among medicare beneficiaries receiving implantable cardioverter-defibrillators. J. Am. Coll. Cardiol. 2006, 48, 1782-1790. [CrossRef]

10. Ram, P.A.; Waxman, J.D. OCS/CIS protein inhibition of growth hormone-stimulated STAT5 signaling by multiple mechanisms. J. Biol. Chem. 1999, 274, 35553-35561. [CrossRef]

11. Hoshino, Y.; Kodama, T.; Okahata, Y.; Shea, K.J. Peptide imprinted polymer nanoparticles: A plastic antibody. J. Am. Chem. Soc. 2008, 130, 15242-15243. [CrossRef]

12. Hoshino, Y.; Koide, H.; Urakami, T.; Kanazawa, H.; Kodama, T.; Oku, N.; Shea, K.J. Recognition, Neutralization, and Clearance of Target Peptides in the Bloodstream of Living Mice by Molecularly Imprinted Polymer Nanoparticles: A Plastic Antibody. J. Am. Chem. Soc. 2010, 132, 6644-6645. [CrossRef]

13. Takeuchi, T.; Kitayama, Y.; Sasao, R.; Yamada, T.; Toh, K.; Matsumoto, Y.; Kataoka, K. Molecularly Imprinted Nanogels Acquire Stealth In Situ by Cloaking Themselves with Native Dysopsonic Proteins. Angew. Chem. Int. Ed. 2017, 56, 7088-7092. [CrossRef]

14. Wang, X.; Wang, L.; He, X.; Zhang, Y.; Chen, L. A molecularly imprinted polymer-coated nanocomposite of magnetic nanoparticles for estrone recognition. Talanta 2009, 78, 327-332. [CrossRef]

15. Griffete, N.; Li, H.; Lamouri, A.; Redeuilh, C.; Chen, K.; Dong, C.-Z.; Nowak, S.; Ammar, S.; Mangeney, C. Magnetic nanocrystals coated by molecularly imprinted polymers for the recognition of bisphenol A. J. Mater. Chem. 2012, 22, 1807-1811. [CrossRef]

16. Zhang, X.; Du, X.; Huang, X.; Lv, Z. Creating protein-imprinted self-assembled monolayers with multiple binding sites and biocompatible imprinted cavities. J. Am. Chem. Soc. 2013, 135, 9248-9251. [CrossRef] [PubMed]

17. Canfarotta, F.; Lezina, L.; Guerreiro, A.; Czulak, J.; Petukhov, A.; Daks, A.; Smolinska-Kempisty, K.; Poma, A.; Piletsky, S.; Barlev, N. Specific Drug Delivery to Cancer Cells with Double-Imprinted Nanoparticles against Epidermal Growth Factor Receptor. Nano Lett. 2018, 18, 4641-4646. [CrossRef] [PubMed]

18. Koide, H.; Yoshimatsu, K.; Hoshino, Y.; Lee, S.-H.; Okajima, A.; Ariizumi, S.; Narita, Y.; Yonamine, Y.; Weisman, A.C.; Nishimura, Y.; et al. Specific Drug Delivery to Cancer Cells with Double-Imprinted Nanoparticles against Epidermal Growth Factor Receptor. Nat. Chem. 2017, 9, 715-722. [CrossRef]

19. Cutivet, A.; Schembri, C.; Kovensky, J.; Haupt, K. Molecularly Imprinted Microgels as Enzyme Inhibitors. J. Am. Chem. Soc. 2009, 131, 14699-14702. [CrossRef] [PubMed]

20. Pan, G.; Shinde, S.; Yeung, S.Y.; Jakstaite, M.; Li, Q.; Wingren, A.G.; Sellergren, B. An Epitope-Imprinted Biointerface with Dynamic Bioactivity for Modulating Cell-Biomaterial Interactions. Angew. Chem. Int. Ed. 2017, 56, 15959-15963. [CrossRef]

21. Boitard, C.; Bée, A.; Ménager, C.; Griffete, N. Magnetic protein imprinted polymers: A review. J. Mater. Chem. B 2018, 6, 1563-1580. [CrossRef] [PubMed]

22. Kan, X.; Zhao, Q.; Shao, D.; Geng, Z.; Wan, Z.; Zhu, J.-J. Difference in Hydration between Carboxybetaine and Sulfobetaine. J. Phys. Chem. B 2010, 114, 16625-16631. [CrossRef]

23. Gao, R.; Kong, X.; Wang, X.; He, X.; Chen, L.; Zhang, Y. Preparation and characterization of uniformly sized molecularly imprinted polymers functionalized with core-shell magnetic nanoparticles for the recognition and enrichment of protein. J. Mater. Chem. 2011, 21, 17863-17871. [CrossRef]

24. Asadi, E.; Abdouss, M.; Leblanc, M.R.; Ezzati, N.; Wilson, N.J.; Azodi-Deilami, S. Synthesis and in vitro biological evaluation of novel diaminothiophene scaffolds as antitumor and antiinfluenza virus agents. RSC Adv. 2016, 6, 37308-37318. [CrossRef]

25. Fortin, J.-P.; Wilhelm, C.; Servais, J.; Ménager, C.; Bacri, J.-C.; Gazeau, F. Size-Sorted Anionic Iron Oxide Nanomagnets as Colloidal Mediators for Magnetic Hyperthermia. J. Am. Chem. Soc. 2007, 129, 2628-2635. [CrossRef] [PubMed]

26. Dias, J.T.; Moros, M.; del Pino, P.; Rivera, S.; Grazú, V.; de la Fuente, J.M. DNA as a molecular local thermal probe for the analysis of magnetic hyperthermia. Angew. Chem. Int. Ed. 2013, 52, 11526-11529. [CrossRef]

27. Riedinger, A.; Guardia, P.; Curcio, A.; Garcia, M.A.; Cingolani, R.; Manna, L.; Pellegrino, T. Subnanometer Local Temperature Probing and Remotely Controlled Drug Release Based on Azo-Functionalized Iron Oxide Nanoparticles. Nano Lett. 2013, 13, 2399-2406. [CrossRef] [PubMed]

28. Cazares-Cortes, S.E.; Cabana, S.; Boitard, C.; Nehlig, E.; Griffete, N.; Fresnais, J.; Wilhelm, C.; Abou-Hassan, A.; Ménager, C. Recent insights in magnetic hyperthermia: From the "hot-spot" effect for local delivery to combined magneto-photo-thermia using magneto-plasmonic hybrids. Adv. Drug Deliv. Rev. 2019, 138, 233-246. [CrossRef]

29. Boitard, C.; Rollet, A.-L.; Ménager, C.; Griffete, N. Surface-initiated synthesis of bulk-imprinted magnetic polymers for protein recognition. Chem. Commun. 2017, 53, 8846-8849. [CrossRef]

30. Otsu, T.J. Iniferter concept and living radical polymerization. Polym. Sci. Part Polym. Chem. 2000, 38, 2121-2136. [CrossRef]

31. Guibert, C.; Fresnais, J.; Peyre, V.; Dupuis, V. Magnetic fluid hyperthermia probed by both calorimetric and dynamic hysteresis measurements. J. Magn. Magn. Mater. 2016, 421, 384-392. [CrossRef]

32. Guibert, C.; Dupuis, V.; Peyre, V.; Fresnais, J. Hyperthermia of Magnetic Nanoparticles: Experimental Study of the Role of Aggregation. J. Phys. Chem. C 2015, 50, 28148-28154. [CrossRef] 